\title{
Teologiekroniek - Die kerk en ekonomiese globalisering
}

D E de Villiers

(Universiteit van Pretoria)

\section{INLEIDING}

Die mees ingrypende ontwikkeling op ekonomiese gebied van die afgelope dekades is ongetwyfeld ekonomiese globalisering. Tot heel onlangs is meestal in gloeiende positiewe terme oor ekonomiese globalisering gepraat. Ekonome het nie geskroom om dit as die heilmiddel vir sukkelende ekonomieë in ontwikkelingslande voor te hou nie. Vandag is daar nog steeds baie ekonome wat oordeel dat die voordele daaraan verbonde veel meer is as die nadele. Tog is die entoesiasme daaroor meer gedemp. Die grootskaalse betogings teen ekonomiese globalisering in Seattle, Davos en Genoa - en op kleiner skaal ook in Suid-Afrika - het uitgewys dat daar ook groeiende verset is. Ekonomiese globalisering word deur teenstanders as die hoofoorsaak van die groeiende ekonomiese ongelykheid en werkloosheid in sowel ontwikkelings- as ontwikkelde lande beskou.

Die kerk kan die huidige debat oor ekonomiese globalisering nie ignoreer nie. Dié debat het nie net te doen met die suiwer ekonomiese vraag of dit die mees effektiewe ekonomiese stelsel is waaroor ons tans beskik nie. Dit gaan ook oor die morele vraag of dit bydra tot groter geregtigheid in die wêreld en of dit eerder groter ekonomiese ongelykheid en armoede bevorder. En dit gaan ook oor die vraag wat die taak van die kerk is ten aansien van ekonomiese globalisering en die uitwerking daarvan.

Dit is onmoontlik om in hierdie kroniek volledige antwoorde op hierdie twee vrae te kry. Daar word eerder aanvoorwerk gedoen vir ' $n$ deeglike en omvattende kerklike debat oor ekonomiese globalisering. Eers word probeer om vas te stel wat ekonomiese globalisering is en wat die faktore is wat daartoe bygedra het. Daarna word aandag gegee aan die uitwerking van ekonomiese globalisering. Ten slotte word verskillende vlakke onderskei waarop die kerk betrokke sou kon raak om die negatiewe uitwerking van ekonomiese globalisering te verlig.

\section{WAT BEHELS EKONOMIESE GLOBALISERING?}

Alhoewel ekonomiese globalisering op die oomblik die meeste aandag trek, is dit nie die enigste vorm van globalisering nie. Dit maak eerder deel uit van ' $n$ omvattende proses van globalisering wat die menslike bestaan op aarde ingrypend beïnvloed. In hierdie proses kan verskillende dimensies onderskei word. As gevolg van die fenomenale ontwikkeling 
van inligtingstegnologie, beskik ons vandag feitlik onmiddellik oor inligting oor wat in lande dwarsoor die wêreld gebeur (inligtingsglobalisering). Beter kommunikasie maak dit moontlik dat mense in verskillende lande kan saamwerk om ' $n$ bepaalde produk tot stand te bring en selfs vanuit een land take in ander lande kan uitvoer (globalisering van samewerking op die gebied van arbeid). Kultuurprodukte uit een wêrelddeel, byvoorbeeld Amerikaanse rolprente, word oor die wêreld versprei en oefen ' $n$ wêreldwye kulturele invloed uit (kulturele globalisering). Omgewingsbesoedeling wat in een land plaasvind, het dikwels in ander lande en wêrelddele ' $n$ negatiewe ekologiese uitwerking (ekologiese globalisering). Transnasionale saketransaksies van biljoene rande word daagliks, soms net met die druk van ' $n$ rekenaarknoppie, tussen besighede in verskillende lande beklink (ekonomiese globalisering). Diegene wat in Seattle en Davos van dwarsoor die wêreld gekom het om teen transnasionale maatskappye in die naam van ekonomiese geregtigheid te betoog, het die betoging vooraf deur middel van e-pos georganiseer (globalisering van die stryd om ekonomiese geregtigheid).

Wat al hierdie vorme van globalisering van blote internasionalisering onderskei, is dat dit nie maar net groter samewerking tussen verskillende nasiestate behels nie, maar ' $\mathrm{n}$ proses wat juis die politieke, ekonomiese en kulturele grense wat deur die nasiestate opgerig is, deurkruis en laat vervaag. Nie alleen word fisiese afstande tussen mense oorbrug nie, maar word ook afstande tussen verskillende kultuurvorme, ekonomiese en politieke stelsels minder. Steeds meer deel mense dwarsoor die wêreld in gemeenskaplike lewensvorme. Aan die ander kant is daar ' $n$ hernude oplewing van belangstelling in plaaslike kultuurvorme. Dit weerspreek egter nie die groeiende gemeenskaplikheid in lewensvorme nie, maar moet eerder gesien word as ' $n$ poging om daarvoor te kompenseer.

Ekonomiese globalisering kan omskryf word as die proses van groeiende interaksie in wêreldhandel, buitelandse investering en op buitelandse kapitaalmarkte. Die volgende syfers illustreer dié groeiende interaksie:

- Die volume van wêreldhandel in 1997 was 16 keer soveel as wat dit in 1950 was, terwyl die totale opbrengs in die wêreld slegs vyf-en-'nhalf keer soveel was. Die ratio van wêrelduitvoere tot Bruto Nasionale Produk (BNP) het geklim van $7 \%$ tot $15 \%$.

- Aan die einde van 1996 was die totale aandeel van besighede in direkte investeringe buite hul eie land oor die $\$ 3$ triljoen ${ }^{1}$. Aan die

\footnotetext{
1 ' $\mathrm{n}$ Miljoen is 1 met 6 nulle ( 1000000$)$. ' $n$ Biljoen is ' $n$ duisend miljoen ( 9 nulle).

' $n$ Triljoen is ' $n$ miljoen miljoen (12 nulle).
} 
einde van 1998 was dit oor die $\$ 4$ triljoen. Wêreldwyd het buitelandse direkte investering $3 \mathrm{keer}$ vinniger gegroei as totale investering.

- In 1973 was die tipiese daaglikse bedrag geld wat op die buitelandse wisselmark verhandel is $\$ 10-20$ biljoen. Teen 1992 is ongeveer $\$ 900$ biljoen verhandel. Dit word bereken dat die daaglikse omset in 1996 $\$ 1.2$ triljoen was.

Veral twee faktore het hierdie toename in die vloei van goedere en geld gedryf:

- Tegnologiese ontwikkeling. Die koste van kommunikasie en die aanwending van rekenaars, byvoorbeeld, het as gevolg van die tegnologiese ontwikkeling drasties geval en daartoe bygedra dat die natuurlike hindernisse van tyd en ruimte wat nasionale markte skei ook weggeval het. Waar ' $n 3$ minute telefoonoproep tussen New York en London in 1930 nog oor die $\$ 300$ (in 1997 se terme) gekos het, was die koste in 1997 slegs $\$ 1$. Die koste van rekenaarprosessering het met ' $n$ gemiddelde van $30 \%$ ' $n$ jaar in reële terme oor die afgelope aantal dekades geval. Tegnologiese ontwikkeling het ook daartoe bygedra dat die koste om goedere by die mark te kry drasties geval het. Die wêreldekonomie het eerstens veel minder vervoer-intensief as vroeër geword. Wêreldhandel het aan die begin van die 20 ste eeu nog vernaamlik in roumateriale wat swaar weeg en baie ruimte inneem, geskied. Vandag oorheers klaar vervaardigde produkte die wêreldhandel. Produkte word daarby dikwels van steeds ligter materiale en ook veel meer kompak gemaak (vergelyk die kompakskyf). Minder vervoer is dus nodig vir elke rand se waarde van invoere of uitvoere. Tweedens het ook die vervoerbedryf ingrypende ontwikkelinge ondergaan wat dit veel goedkoper en makliker maak om goedere rondom die wêreld te vervoer. ' $n$ Reeks tegnologiese ontwikkelinge, breedweg bekend as "behouering" en "intermodale vervoer" het daartoe gelei dat produktiwiteit in die hantering van vrag binne enkele jare sterk toegeneem het.

- Liberalisering. In Julie 1944 het afgevaardigdes van 44 lande in Bretton Woods, New Hampshire, VSA byeengekom en in vier weke die grondslae gelê vir die na-oorlogse internasionale ekonomiese orde. Die sogenaamde Bretton Woods stelsel sou op vier pilare berus: ' $n$ Internasionale Bank vir Heropbou en Ontwikkeling, nou bekend as die Wêreldbank, wat kapitaal vir heropbou en ontwikkeling sou voorskiet; die Internasionale Monitêre Fonds (IMF) wat internasionale samewerking ten aansien van monitêre beleid en stabiliteit ten aansien van wisselkoerse sou bevorder; die Internasionale Handelsorganisasie wat vrye internasionale handel sou bevorder; en die Verenigde Nasies (VN). Die Internasionale Handelsorganisasie het nooit tot 
stand gekom nie. In die plek daarvan is ' $n$ reeks internasionale ooreenkomste gesluit, die sogenaamde GATT (General Agreement on Tariffs and Trade) wat daarin geslaag het om invoerheffinge geleidelik te verlaag. In 1995 is GATT vervang met die Wêreldhandelsorganisasie wat die proses van die verlaging en selfs opheffing van invoerheffinge versnel het. Waar die uitfasering van invoertariewe veral die wêreldhandel in goedere gestimuleer het, het die afskaffing van die stelsel van vaste wisselkoerse - waaraan nog by Bretton Woods vasgehou is - in die vroeë sewentigerjare en die invoering van ' $n$ stelsel wat geldeenhede toelaat om te "dryf" volgens die relatiewe waarde wat die kapitaalmark daaraan toeken, daartoe bygedra dat die omset van die internasionale kapitaalmark drasties verhoog het.

Daar is egter nog twee ander bydraende faktore wat nie buite rekening gelaat kan word nie:

- Die einde van die Koue Oorlog en die ineenstorting van sentraal beplande ekonomieë. Tydens die Koue Oorlog was die wêreld verdeel in die sogenaamde Eerste, Tweede en Derde Wêrelde met hul eie politieke en ekonomiese identiteite. $\mathrm{Na}$ die ineenstorting van die Kommunistiese stelsel het ideologiese verskille al meer op die agtergrond getree. In die ideologiese lugleegte wat ontstaan het, het die vryemarkstelsel wêreldwyd - ook in lande wat vroeër sterk daarteen gekant was - groter invloed en aansien verkry. Selfs die stelsel van die sosiale markekonomie (of welsynstaat), wat vroeër as alternatief tussen die sosialistiese en vryemarkstelsel aanhang geniet het, het onder druk gekom. ' $n$ Neo-liberale beskouing van die vryemarkekonomie wat sterk klem lê op kompetisie en op die beperking van die ekonomiese rol van die staat deur privatisering, deregulering en liberalisering het die heersende ekonomiese beskouing geword. Voorstanders van die neo-liberale beskouing het groot invloed in organisasies soos die Wêreldbank en die IMF uitgeoefen. Via hierdie organisasies het hulle druk op veral ontwikkelingslande uitgeoefen om hul ekonomieë te dereguleer en te liberaliseer en staatsondernemings te privatiseer en so die globalisering van die ekonomie, te bevorder.

- Die rol van trans- of multinasionale maatskappye. Hierdie maatskappye is ongetwyfeld een van die hoofkanale vir die vestiging en uitbreiding van ekonomiese globalisering. Die aantal transnasionale maatskappye het van ongeveer 7000 in 1970 tot ongeveer 39000 in 1995 toegeneem. In 1995 het hulle ongeveer \$7 triljoen omset in verkope deur hulle buitelandse filiale gehad - ' $n$ bedrag wat groter was as die wêreld se totale uitvoer. Hulle speel ook 'n belangrike rol in die disseminasie van tegnologie in die wêreld en in buitelandse direkte investering. Hulle besit of kontroleer $86 \%$ van die wêreld se grond 
wat uitvoerprodukte kweek, kontroleer $60 \%$ van die aluminiummynbou en verkoop $90 \%$ van die agrochemiese produkte. Sommige transnasionale maatskappye is finansieel sterker as talle nasionale ekonomieë: die jaarlikse verkope van die Shell maatskappy, byvoorbeeld, is twee keer soveel as Nieu Seeland se BNP.

\section{WAT IS DIE UITWERKING VAN EKONOMIESE GLOBALI- SERING?}

Sedert die vroeë neëntigerjare het die Departement van Finansies van die VSA, die IMF en die Wêreldbank 'n neo-liberale beskouing van die wêreldekonomie (op grond van wat bekend geword het as die "Washington konsensus") aggressief bemark. Dié beskouing het daarop neergekom dat alle lande hul markte so gou as moontlik vir handel, direkte investering en kort-termyn kapitaal moet oopmaak. Die oorgang sou pynlik wees, maar die resultaat sou markstabiliteit en voorspoed wees. In ' $n$ onlangse artikel oordeel Business Week (Nov. 6, 2000) soos volg hieroor: "In hindsight, it was a naïve and self-interested view... To be sure, developing nations badly needed to import capital and foreign financial knowhow to keep growing. But many nations simply couldn't handle the inflows. The results were huge white-elephant industrial and property projects that devoured funds and foreign-currency debt bombs that started exploding in 1994, first in Mexico and later in East Asia".

Die neo-liberale beskouing van die voordele van ekonomiese globalisering is gebaseer op die oortuiging dat dit wêreldwyd produktiwiteit sal verhoog en tot ekonomiese voordeel van alle lande en alle mense sal wees. Die teorie is dat vrye internasionale vloei van kapitaal daartoe sal lei dat die investering van spaargeld meer effektief toegewys word. Arm lande kan broodnodige investering uit ryk lande bekom en spaarders in ryk lande kan hul geld wêreldwyd belê waar die beste opbrengs verkry kan word. Onbelemmerde internasionale handel kan meer werkgeleentheid skep in lande wat uitvoer, maar veral daartoe lei dat lande nie probeer om ten duurste produkte te vervaardig wat hulle veel goedkoper van ander lande kan invoer nie, maar eerder konsentreer op die vervaardiging van produkte waarin hulle ' $n$ relatiewe voordeel het (byv. arbeidsintensiewe vervaardiging in lande met goedkoop arbeid).

In die praktyk het dit oor die afgelope dekades geblyk dat sekere lande en sekere mense inderdaad groot ekonomiese voordeel uit ekonomiese globalisering gehaal het, maar dat ander lande en ander mense min of geen baat daarby gevind het nie. Dit was veral die lande in Europa (veral die lande wat deel uitmaak van die Europese Unie), in NoordAmerika en in die sogenaamde soomgebied van die Stille Oseaan (in die besonder Japan, Hong Kong, Taiwan, Singapore en Korea) wat die voordele van ekonomiese globalisering gesmaak het. Baie ontwikkelings- 
lande het egter nie baat daarby gevind nie. Wat algaande duidelik geraak het, is dat lande nie by ekonomiese globalisering baat as hulle nie aan bepaalde minimum-voorwaardes voldoen nie. As ' $n$ land byvoorbeeld polities onstabiel is, die gaping in die bevolking tussen ryk en arm groot is, die regering swak ekonomiese bestuur toepas, ' $n$ behoorlike infrastruktuur ontbreek en ' $n$ groot deel van die bevolking nie behoorlike opleiding ontvang nie, is die kans dat hy voordeel uit ekonomiese globalisering sal haal, maar skraal.

Die probleme wat met ekonomiese globalisering geassosieer word, kan as volg saamgevat word:

Die gaping in die wêreld tussen ryk en arm word groter.

Aangesien ekonomiese globalisering beslis nie alle lande eweveel bevoordeel nie, het 'n dramatiese toename in die inkomste- en welvaartsgaping tussen lande oor die afgelope dekades plaasgevind. In 1960 het die rykste lande 30 keer meer inkomste as die armste $20 \%$ gehad. Nou het die gaping tot 74 keer gegroei. Dit is nie soseer die geval dat alle lande daarby gebaat het, maar sommige net meer as ander nie. Van 1990 tot 1996 het alleen 33 lande daarin geslaag om 'n 3\% jaarlikse groei te handhaaf, terwyl die ekonomieë van 59 lande ingekrimp het. Dit het byvoorbeeld in sub-Sahara Afrika en die ou Oosbloklande teweeggebring dat gemiddelde inkomste oor die afgelope dekades in reële terme gekrimp het. Die Wêreldbank het bereken dat die aantal mense in die wêreld wat op slegs $\$ 1$ ' $n$ dag moet leef oor die afgelope dekade tot 1.3 biljoen toegeneem het. Alhoewel die persentasie van die totale bevolking in Afrika wat in sulke armoede leef nie oor die afgelope dekade toegeneem het nie, het dit van alle wêrelddele nog steeds die hoogste persentasie absoluut arm mense ${ }^{2}$, naamlik meer as $45 \%$ van die totale bevolking.

Alhoewel die aantal swartmense in Suid-Afrika wat ' $n$ hoër inkomste verdien oor die afgelope dekades toegeneem het, neem dit nie weg nie dat die gaping tussen ryk en arm nog steeds besonder hoog is - die Gini-koëffisiënt (wat ekonomiese ongelykheid uitdruk) vir Suid-Afrika is 0.69 , die hoogste van alle lande in die wêreld. Daar is nog ' $n$ groot persentasie van die bevolking wat in absolute armoede verkeer. By die "National Programme of Action of the War on Poverty Forum" in Oktober 1998 is beweer dat $53 \%$ van die Suid-Afrikaanse bevolking onder die broodlyn van R301 (\$43) per maand leef. Die armste $40 \%$ van alle huishoudings, dit wil sê $50 \%$ van die bevolking, verdien slegs $11 \%$ van die totale inkomste, terwyl die rykste $10 \%$ van die huishoudings, gelyk aan $7 \%$ van die bevolking, oor die $40 \%$ van die inkomste verdien.

${ }^{2}$ Die "absoluut arm mense" is daardie wat met minder as $\$ 1$ per dag moet deurkom. 
Die geweldige toename in ekonomiese groei in sekere lande en die gebrek aan ekonomiese groei in ander lande kan in ' $n$ belangrike mate toegeskryf word aan die oneweredigheid van die buitelandse direkte investering oor die afgelope dekades. Alhoewel dit geweldig toegeneem het tot ongeveer $\$ 400$ biljoen jaarliks, gaan $80 \%$ daarvan na slegs 10 lande, terwyl 100 lande jaarliks gemiddeld slegs $\$ 100$ miljoen buitelandse direkte investering aantrek. Die rede is dat beleggers juis in dié lande met die beste groeivooruitsigte belê. Een van die faktore waarna die eienaars van transnasionale maatskappye byvoorbeeld kyk voordat hulle in ' $n$ land belê, is of daar ' $n$ binnelandse mark is vir die produkte wat hulle vervaardig. Aangesien die groeivooruitsigte in Asië in 1996 rooskleurig gelyk het, het tweederdes van die totale investering in ontwikkelingslande in dié jaar, ongeveer $\$ 80$ biljoen, in Asië (met Japan buite rekening gelaat) plaasgevind. Latyns-Amerika het ongeveer $\$ 39$ biljoen aan buitelandse direkte investering ingepalm. In 1998, met die finansiële krisis in Oos-Asië, kon die lande in Asië slegs die helfte van die investeringskapitaal aantrek ( $\$ 85$ biljoen uit $\$ 165$ biljoen), in vergelyking met Latyns-Amerika se $\$ 72$ biljoen. Sub-Sahara Afrika kon in vergelyking daarmee slegs ' $n$ onbeduidend klein gedeelte van die buitelandse direkte investering aantrek. In 1998 het dit nog nie $\$ 5$ biljoen behels nie. Die vernaamste rede is dat daar nie " $n$ sterk genoeg mark vir Eerste Wêreld verbruikersartikels in Afrika is nie.

Nog ' $n$ faktor wat bygedra het tot baie ontwikkelingslande se swak ekonomiese situasie, is hul groot buitelandse skuldlas. In die sestigerjare het baie van dié lande teen lae rentekoerse groot lenings in die Weste bekom. Met die skerp styging van die olieprys in 1973 en veral in 19791980 is hulle egter in 'n ekonomiese krisis gedompel. Rentekoerse het skerp gestyg, terwyl die prys van roumateriale waarop die ekonomieë van baie ontwikkelingslande gebaseer was, vanweë ' $n$ verminderde aanvraag in Eerste Wêreldlande skerp gedaal het. Ontwikkelingslande het dit steeds moeiliker gevind om hul buitelandse skuld te delg. Van die 54 lande wat die Wêreldbank as "lae-inkomstelande" klassifiseer, het 32 'n ernstige skuldprobleem. Omtrent al dié lande is in Afrika. Aangesien dié lande ' $n$ buitengewoon groot gedeelte van die staatsinkomste moet aanwend om hul buitelandse skuld af te betaal, kan hulle baie min investeer in die ontwikkeling van behoorlike infrastruktuur, onderwys, gesondheidsorg en welsynsdienste. Dit beteken nie alleen dat hul bevolking die prys moet betaal vir die groot skuldlas nie, maar ook dat hulle nie in die wêreldekonomie kan kompeteer met lande wat veel meer in byvoorbeeld infrastruktuur en onderwys investeer nie.

Om te verseker dat lande met ' $\mathrm{n}$ hoë skuldlas in staat sal wees om hul skulde terug te betaal, het beide die IMF en die Wêreldbank begin om die invoering van bepaalde makro-ekonomiese maatreëls as voorwaarde vir die toestaan en herstrukturering van lenings neer te lê (die 
sogenaamde Strukturele Aanpassingsprogramme, afgekort: SAP). Dié lande moes hul geldeenhede devalueer om uitvoere aan te wakker, rentekoerse verhoog om binnelandse spaar te stimuleer, nasionale begrotings sny, staatseiendom privatiseer en die ekonomie liberaliseer. In min gevalle het dié maatreëls die gewenste uitwerking gehad. Dit het eerder meestal daartoe bygedra dat die bevolking in lande met skuld nog meer gely het. In plaas van die verwagte ekonomiese opbloei en grootskaalse werkskepping, het maatreëls soos die verkleining van staatsdienste en die privatisering van staatsondernemings eerder teweeggebring dat die aantal werkloses en armes in dié lande verder toegeneem het.

\section{Toenemende werkloosheid en gebrekkige arbeidsekuriteit}

'n Mens sou verwag dat ekonomiese globalisering vanweë die groot toename in buitelandse direkte investering en wêreldhandel ook sou lei tot ' $n$ groot toename in werkskepping. Die verrassende resultaat is egter dat die ekonomiese groei nie met 'n dienoorkomstige groei in werkgeleentheid gepaard gegaan het nie. Die verskynsel van "werklose groei" is ' $n$ bekende verskynsel in die hedendaagse wêreldekonomie. In dié lande waar daar wel ' $n$ toename in werkgeleentheid was, het dit dikwels gepaard gegaan met ' $n$ verlaging in reële lone, swak en onveilige werksomstandighede en ' $n$ verlies aan werksekuriteit.

Wêreldwyd het werkloosheid oor die afgelope dekades toegeneem. Dit is nie net in ontwikkelingslande die geval nie, maar ook in voormalige Kommunistiese lande en in ontwikkelde lande. In Hungarye en Bulgarye waar die Kommunistiese stelsel voorheen aan almal ' $n$ werk gewaarborg het, het die werkloosheid in die neëntigerjare tot $30 \%$ toegeneem. In ontwikkelde lande (die sogenaamde OECD-lande) het die aantal werkloses tot 35 miljoen toegeneem. Veral vroue en jongmense word daardeur geraak. In Australië is $70 \%$ van die vroue werkloos en in sommige Europese lande $60 \%$ van jongmense wat die skool verlaat. Meerdere faktore lewer hiertoe ' $n$ bydrae. Dat die groter kompetisie tussen maatskappye as gevolg van ekonomiese globalisering ook daartoe ' $n$ bydrae lewer, kan egter nie ontken word nie. Maatskappye word genoop om hul personeeluitgawes so laag as moontlik te hou om die pryse van hul produkte op die wêreldmark kompeterend te hou. Een manier is om te probeer om die aantal werknemers te rasionaliseer sonder om produksie te verlaag. Tussen 1980 en 1993 het die wêreld se 500 grootste maatskappye dan ook 4.4 miljoen poste afgeskaf, terwyl hul verkope 1.4 keer toegeneem het en hul bates 2.4 keer.

Die situasie in Suid-Afrika weerspieël die tendens wêreldwyd. Met die aanvaarding van GEAR het die regering voorsien dat honderde duisende poste oor die afgelope aantal jare geskep sou word. Die werklikheid was egter anders. Volgens een berekening het Suid-Afrika sedert 1994 een miljoen werkgeleenthede in die formele sektor verloor, terwyl 
daar jaarliks ongeveer ' $n$ halfmiljoen skoolverlaters is. Die gemiddelde werkloosheidsyfer vir die land is ongeveer $30 \%$, maar is in sommige dele van die land byna $50 \%$.

Nog ' $n$ manier waarop maatskappye hul personeeluitgawes probeer verminder, is deur die toepassing van die beginsel van arbeidsoepelheid. Die korps van permanente werknemers met relatief hoë salarisse en volle werknemersvoordele word so klein as moontlik gehou. Die res van die werknemers bestaan uit kontrak- en stukwerkers wat op ' $n$ tydelike basis in diens geneem word. Sulke werkers kan vinnig in diens geneem word as daar ekstra werkkragte benodig word, maar kan net so vinnig ontslaan word as die ekonomie afkoel en laer produksie vereis word. Dit het tot gevolg dat ' $n$ groot aantal werkers, in ontwikkelings- en ontwikkelde lande, vandag veel minder arbeidsekuriteit as voorheen het. Regerings is geneig om toe te gee aan die druk om minimumlone te verlaag en maatreëls wat arbeidsekuriteit verseker, af te swak. Hulle is maar te bewus daarvan dat groot transnasionale maatskappye nie skroom om fabrieke te sluit in ' $n$ land wat relatief hoë minimumlone en arbeidsekuriteit afdwing en na lande te verskuif waar minimumlone laer en arbeidswetgewing meer soepel is nie.

Aangesien transnasionale maatskappye so'n sterk bedingingsmag het, slaag hulle dikwels daarin om uiters lae lone te betaal aan die werkers in hul of hul affiliale se fabrieke in ontwikkelingslande en buitensporig hoë winste op hul produkte te behaal. TYI, 'n maatskappy in Indonesië wat vir Reebok sportskoene vervaardig, betaal byvoorbeeld $22 \varnothing$ (van ' $n$ dollar) per uur aan sy werkers (nog steeds effens hoër as die minimumloon in Indonesië). Die arbeidsloon per een paar skoene is slegs $\$ 1$. Reebok verkoop ' $n$ paar skoene uiteindelik vir tussen $\$ 60$ en $\$ 70$. Daar is ook baie gevalle bekend waar werkers in haglike en gevaarlike omstandighede moet werk, gedwing word om sonder oortydbetaling buitengewoon lang ure per dag of sewe dae per week te werk of selfs lyfstraf toegedien word as hulle laat kom (die sogenaamde "sweatshops").

\section{Ander probleme}

Afgesien van die steeds groter gaping tussen ryk en arm, toenemende werkloosheid en gebrekkige arbeidsekuriteit, is daar ook ' $n$ aantal ander probleme wat met ekonomiese globalisering geassosieer word:

- Die afswakking van regerings van nasiestate se mag om ekonomiese beleid te bepaal ooreenkomstig die wense van hul burgers en beheer uit te oefen oor die ekonomie van hul land.

- Die blootstelling van veral ontwikkelingslande aan monetêre krisisse, omdat groot bedrae kort-termyn kapitaal baie vinnig aan ' $n$ land onttrek kan word as beleggers vermoed dat hul beleggings nie die verwagte opbrengs sal bring nie. 
- Dit is makliker om in ' $n$ gedereguleerde wêreldekonomie bedrog en korrupsie te pleeg (byv belastingbedrog) en veel moeiliker vir regerings om dit te bekamp.

- Transnasionale maatskappy het dikwels slegs die bevordering van hul eie geldelike belang op die oog en openbaar daarom min sosiale verantwoordelikheid, byvoorbeeld om die omgewing van die lande waar hulle werksaam is, te bewaar.

- Kultuurprodukte, veral films, van die kapitaalkragtige VSA word wêreldwyd versprei en dreig om plaaslike kultuurprodukte te verdring.

\section{VLAKKE VAN KERKLIKE BETROKKENHEID}

Oor die vraag of daar iets gedoen kan word om die probleme wat met ekonomiese globalisering geassosieer word, uit die weg te ruim, is daar al baie gedebatteer. Om die bespreking van dié vraag meer hanteerbaar te maak, kan vier vlakke van moontlike optrede onderskei word:

\section{Transformasie van die wêreld ekonomiese orde}

Menings loop uiteen oor of die huidige stelsel van ekonomiese globalisering enigsins hervormbaar is. Daar is diegene wat oordeel dat daar vanweë veral die fenomenale ontwikkelinge op die gebied van die inligtingstegnologie én die totale afwesigheid van ander geloofwaardige ekonomiese stelsels geen ander alternatief vir die huidige vryemarkgebaseerde stelsel van ekonomiese globalisering is nie (die sogenaamde TINA: There Is No Other Alternative-standpunt). Voorstanders van die TINA-standpunt is gewoonlik diegene wat die meeste by ekonomiese globalisering baat. In plaas van om ' $n$ futiele poging aan te wend om die stelsel van ekonomiese globalisering omver te werp of te transformeer, moet regerings eerder, volgens voorstanders van dié standpunt, hul eie huis in orde kry en sorg dra dat die ekonomieë van hul eie lande afgestem is op ekonomiese globalisering. Ander oordeel dat die stelsel van ekonomiese globalisering niks anders is as 'n feilbare mensgemaakte stelsel nie en daarom beslis hervormbaar is. In ekumeniese kringe in Suid-Afrika word dié standpunt toenemend aangedui as die THEMBA: There Must Be An Alternative-standpunt. (In Zoeloe en Xhosa beteken "themba" "hoop" en "betroubaarheid"). Voorstelle vir die transformasie van die huidige stelsel wat deur voorstanders van laasgenoemde standpunt gemaak word, wissel van die transformasie van die bestaande organisasies wat die wêreldekonomie reguleer (organisasies soos die IMF, die Wêreldbank en die Wêreldhandelsorganisasie) om dit meer demokraties en deursigtig te maak, versterking van die kontrolefunksie van dergelike organisasies om monitêre krisisse, korrupsie en bedrog te voorkom en toe te sien dat die omgewing bewaar word, tot maatreëls om die 
posisie van die arm lande in die wêreldekonomie te versterk (byv die afskryf van die skuld van die armste lande en effektiewe en omvattende ontwikkelingshulp).

\section{REGERINGSMAATREËLS OM DIE NEGATIEWE UITWER- KING VAN EKONOMIESE GLOBALISERING TE VOORKOM}

Die standpunt van die IMF en die Wêreldbank aan die begin van die neëntigerjare was dat regerings slegs bepaalde makro-ekonomiese maatreëls moet neem om die voordele van ekonomiese globalisering te smaak. Daar is egter ' $n$ groeiende konsensus dat die neem van sulke maatreëls nie afdoende is om te verseker dat ' $n$ bepaalde land daardeur bevoordeel word nie. Om byvoorbeeld ' $n$ ontwikkelingsland teen monitêre krisisse te beskerm as gevolg van die vinnige in- en uitvloei van kort-termyn kapitaal kan dit nodig wees om tog kontrolemaatreëls in te stel om die vloei van buitelandse kapitaal te reël (soos die Poolse regering). Regerings kan ook strenger optree teen transnasionale maatskappye wat onaanvaarbare arbeidspraktyke toepas, die omgewing besoedel en hulle skuldig maak aan bedrog. Hulle het ook ' $n$ besondere verantwoordelikheid om genoegsaam in die opleiding van hul inwoners te investeer om hulle vir die uitdagings van ekonomiese globalisering voor te berei. Hulle behoort kleinskaal plaaslike ontwikkeling te stimuleer en ' $n$ veiligheidsnet daar te stel om te verseker dat diegene wat nie deel in die voordele van ekonomiese globalisering nie, wel ' $n$ bestaan kan maak.

\section{Maatreëls wat maatskappye kan neem om die negatiewe praktyke wat met ekonomiese globalisering gepaard gaan, te vermy}

Vanweë die slegte publisiteit wat transnasionale maatskappye oor die afgelope aantal jare gekry het vanweë swak arbeidspraktyke, betrokkenheid by korrupsie en bedrog en die besoedeling van die omgewing, is daar ' $n$ toenemende aantal van dié maatskappye wat hulself verbind tot die nakoming van etiese kodes. Sommige van hulle, byvoorbeeld die speelgoedmaatskappy Mattel, onderwerp hulle ook aan gereelde monitering deur buitestanders om hul nakoming van dié etiese kodes te verseker.

\section{Hulpverlening wat deur organisasies in die burgerlike samelewing verleen kan word aan diegene wat nie deel in die voordele van eko- nomiese globalisering nie}

Dit is duidelik dat daar " $n$ toenemende aantal mense in die wêreld is - in ontwikkelingslande sowel as ontwikkelde lande - wat nie deel uitmaak van die formele wêreldekonomie nie, en waarskynlik nooit deel daarvan sal uitmaak nie. Toenemend is dit slegs mense wat oor bepaalde vaardighede beskik wat daarin slaag om permanente werk te kry. Aangesien 
daar veral in ontwikkelingslande ' $n$ groot aantal mense is wat nog ongeletterd is, of slegs elementêre skoolopleiding het, kan aanvaar word dat die probleem van werkloosheid en armoede veral daar vir nog ' $n$ lang tyd akuut sal wees. Alternatiewe maniere van ontwikkeling sal nodig wees om te verseker dat hulle tog ' $n$ menswaardige bestaan sal kan maak. Welsynsdienste sal nodig wees om weeskinders, bejaardes en gestremdes te kan opvang. Aangesien die taak so omvattend is, sal die regerings in dié lande bygestaan moet word deur organisasies wat deel vorm van die burgerlike samelewing.

Die institusionele kerk (in die gestalte van ekumeniese organisasies, kerklike denominasies en plaaslike gemeentes) kan en behoort op al vier hierdie vlakke betrokke te wees. Aangesien ekonomiese globalisering by uitstek rykes bevoordeel en vir miljoene arm mense geen voordele inhou nie, het die kerk die profetiese taak om die wêreld ekonomiese orde aan kritiek te onderwerp. Die Wêreld Bond van Gereformeerde Kerke het byvoorbeeld tydens sy Algemene Vergadering in Debrecen, Hongarye in 1997 lidkerke opgeroep tot ' $\mathrm{n}$ processus confessionis, "a committed process of progressive recognition, education and confession... regarding economic injustice and ecological destruction". Ekonomiese maatreëls van regerings wat oënskynlik hul lande beter posisioneer in " $n$ globale ekonomie, maar arm mense nog meer laat ly, en uitbuitende arbeidspraktyke, omgewingsbesoedeling en bedrog deur transnasionale maatskappye behoort ewe-eens aan die profetiese kritiek van die kerk onderwerp te word. Dit is ook deel van die profetiese taak van die kerk om saam te besin oor die rigting waarin die wêreld ekonomiese orde en die ekonomiese beleid van regerings getransformeer moet word om die belange van arm mense beter te kan dien. Verteenwoordigers van kerke kan en behoort ook betrokke te wees by die formulering van morele riglyne wat deel uitmaak van die etiese kodes vir transnasionale maatskappye.

Enige kerk het ' $n$ profetiese taak in dié verband. Aangesien verantwoorde kerklike betrokkenheid op hierdie vlakke besondere kundigheid en ' $n$ interdissiplinêre benadering verg, is dit egter ' $n$ vraag of dit nie ten beste deur ekumeniese organisasies georganiseer kan word nie. Die beste kundigheid uit kerklike denominasies kan so benut en erkende ekonome aangetrek word om met die besinning en formulering van voorstelle te help. ' $n$ Ander voordeel is dat konsensus tussen kerklike denominasies so vinniger bereik kan word en dat kerklike standpunte oor die ekonomie meer gewig sal dra as uit een mond gepraat word.

Daar is nog een vlak waarop ' $n$ kerklike denominasie eie inisiatiewe kan en behoort te neem, naamlik die vlak van hulpverlening aan arm mense wat buite die reikwydte van die wêreldekonomie lê. Die term "hulpverlening" word hier gebruik by gebrek aan 'n beter een. Die hulpverlening wat gevra word, is nie die uitdeel van aalmoese wat arm mense 
verneder en hulle afhanklik van die hulpverleners maak nie. Die uitdaging is om hulpverlening te bied wat armes bemagtig om ' $n$ menswaardige bestaan te voer en hul eie inisiatief en selfstandigheid bevorder. Aan sulke hulpverlening is daar in 'n wêreld wat deur ekonomiese globalisering gekenmerk word, groot behoefte.

\section{Literatuurverwysings}

The Economist 1999. Economics. Making sense of the modern economy. London: Profile Books.

Global capitalism. Can it be made to work better? Special report in: Business Week, European Edition, Nov 6, 2000, 40-68.

South African Catholic Bishops' Conference 1999. Economic justice in South Africa. A pastoral statement. Pretoria: SABC.

Stackhouse, M L; Berger, P L; McCann, D P \& Meeks, M 1995. Christian social ethics in a global era. Nashville: Abingdon Press.

Stackhouse, M L \& Paris, P J (eds) 2000. God and globalization. Vol 1: Religion and the powers of the common life. Harrisburg, Pennsylvania. Trinity Press International.

Van Drimmelen, R 1998. Faith in a global economy. A primer for Christians. Geneva: WCC Publications. 